\title{
Isolation and Identification of Newcastle Disease Virus from Ducks Sold at Traditional Livestock Market Center in Indonesia
}

\author{
Aisyah Nur Azizah ${ }^{1}$, Chairul Anwar ${ }^{1} *$ and Adi Prijo Rahardjo ${ }^{2}$ \\ ${ }^{I}$ Department of Veterinary Anatomy, Faculty of Veterinary Medicine, Universitas Airlangga, Surabaya, East Java, Indonesia \\ ${ }^{2}$ Department of Veterinary Microbiology, Faculty of Veterinary Medicine, Universitas Airlangga, Surabaya, East Java, Indonesia \\ *Corresponding author's Email: chairulhisto@gmail.com; ORCID: 0000-0002-4441-0349
}

Received: 17 Jan. 2021 Accepted: 01 Mar. 2021

\begin{abstract}
Newcastle disease (ND) is one of the important infectious diseases in the poultry industry. The traditional poultry markets have great potential in ND transmission. The ducks infected by the ND virus rarely show clinical symptoms, thus they can potentially spread the disease to other fowls. The current study aimed to isolate and identify the ND virus from ducks in a traditional live bird market center in East Java, Indonesia. Cloacal swab samples were taken from 300 ducks. The study consisted of 100 pooled samples, each containing a cloacal swab sample obtained from 3 individual ducks. The samples were inoculated in specific antibody-negative embryonated chicken eggs for 8-10 days. Hemagglutination and hemagglutination inhibition tests were performed for confirmation and identification of ND virus. Based on the result of the current study, out of 100 pooled samples, there were three to nine ducks infected with the ND virus.
\end{abstract}

Keywords: Cloaca Swab, Duck, Livestock, Newcastle Disease

\section{INTRODUCTION}

Newcastle disease (ND) is one of the important infectious diseases in the poultry industry. Since 1926, ND has been reported as an endemic disease occurring in several countries of the world (Samal, 2011). This disease causes a significant loss for the poultry industry (Hu et al., 2010). The ND is caused by various virus strains. Based on the severity of the disease, ND can be classified into three pathotypes namely lentogenic, mesogenic and velogenic. Although vaccination of commercial chickens is routinely performed in Indonesia, ND remains a major problem in the poultry industry (Samal, 2011).

The traditional poultry markets have great potential in transmitting the ND virus (NDV). Transmission of the disease from the infected fowls to the healthy fowls is caused by various species of fowls which being marketed together. Transmission of NDV can also be caused by different duck maintenance systems ranging from the intensively to extensively maintenance system (Yuliana et al., 2015). The spread of NDV can occur because the fowls which are not sold by the merchant will be taken to other poultry markets, thus the fowls have the potential to be a source of disease in the area (Yuliana et al., 2015).

Unfortunately, there is no information regarding the importance of white Pekin duck as the carrier of NDV, or the potential risk of spreading the disease by Pekin duck to other food-producing fowls that may be looked after close to the Pekin duck habitat (Nishizawa et al., 2007). Although the type of white Pekin duck is resistant to the development of ND clinical signs when challenged with velogenic NDV, the white Pekin duck can shed the virus 20-30 days after the challenge, hence vaccination against ND is very important to reduce virus elimination in the field (Nishizawa et al., 2007).

Remembering insufficient breeders' awareness addressing the importance of biosecurity, vaccination, and separation of ducks and other waterfowl fowls, ducks can act as virus carriers or disease sources that can transmit the disease to other sensitive fowls. Thus, the present study was carried out to isolate and identify the presence of NDV in ducks sold at the traditional livestock market in Indonesia. 


\section{MATERIAL AND METHOD}

\section{Ethical approval}

All experimental protocols and procedures were approved by the Institutional Animal Care of Indonesia.

\section{Samples}

This study was conducted on 300 ducks from the traditional live bird market in Sepanjang area, Sidoarjo, East Java, Indonesia from March to August 2019. The ducks were originated from the regions of Mojosari, Jombang, Lumajang, and Sidoarjo. A purposive sampling method was used to take cloacal swab samples. Sampling was conducted during five weeks and 100 pooled samples (each containing cloacal swab sample from 3 individual ducks) were collected.

\section{Inoculation}

Before sampling, transport media was prepared from $100 \mathrm{ml}$ of $0.9 \% \mathrm{NaCl}$ solution plus penicillin $(1000 \mathrm{IU} / \mathrm{ml}$ of $0.9 \% \mathrm{NaCl}$ solution) and streptomycin $(1 \mathrm{mg} / \mathrm{ml}$ of $0.9 \% \mathrm{NaCl}$ solution). Cloacal swab sample was inserted in a microtube containing the transport media. Each microtube contained three cloaca swabs for one duck. Samples were collected as many as 100 pooled samples. The collected samples were stored in an icebox and taken immediately to the laboratory. Then, the cotton swab was taken using tweezers. The samples were then centrifuged at $2500 \mathrm{rpm}$ for 15 minutes. Furthermore, the virus isolation was carried out by inoculating the sample in the embryonic chicken egg. In the process of inoculation, the embryonic chicken egg used was Specific Antibody Negative (SAN) and aged 8-10 days. This was due to the optimal area of allantoic thus it easier to do inoculation and reduce the risk. After further inoculation, embryonic chicken eggs were incubated in an incubator at $37{ }^{\circ} \mathrm{C}$ for 5 days.

\section{Tests}

The tests were conducted at the Virology and Immunology Laboratory of the Veterinary Microbiology Department, Faculty of Veterinary Medicine, Univesitas Airlangga, Surabaya. The hemagglutination (HA) test was conducted by filling $0.9 \% \mathrm{NaCl}$ solution in all wells (1-12) microplate as much as $25 \mu \mathrm{l}$. Next, $25 \mu \mathrm{l} \mathrm{Ag}$ from the allantoic fluid was inserted into the first row of wells, homogenized $\mathrm{Ag}$, and $0.9 \% \mathrm{NaCl}$ solution using a micropipette, then transferred to the second well. The same procedure was repeated until the $11^{\text {th }}$ well, then $25 \mu 1$ was discarded from the wells 11, and well 12 was used as an erythrocyte control. Following that, $0.5 \%$ of chicken erythrocytes $50 \mu 1$ was added to all wells, shaken slowly, and incubated for 30 minutes at room temperature or $4^{\circ} \mathrm{C}$ for 60 minutes (OIE, 2012). The result was positive in the case of perfect hemagglutination (100\%), where the erythrocyte layer was seen evenly (diffuse) on the base of the microplate. The HA test was negative if erythrocyte sedimentation was in the form of a dot in the middle of the microplate and would form teardrops if tilted.

Hemagglutination inhibition (HI) test was conducted similar to $\mathrm{HA}$, but $0.9 \% \mathrm{NaCl}$ solution was also added with positive antiserum of ND as much as $25 \mu 1$ mixed with $0.9 \% \mathrm{NaCl}$ solution to be homogeneous (used as a replacement, compared with HA test), in wells 1-11. In the HI test, well 12 was used as erythrocyte control. Then, the wells 1-12 were filled with $4 \mathrm{HAU}$ antigens as much as 25 $\mu 1$ using a $25 \mu \mathrm{l}$ micropipette. This antigen was derived from allantoic fluid of embryonic chicken egg which has been diluted using $0.9 \% \mathrm{NaCl}$ solution, according to the titer obtained in the HA test. Microplate incubation was at room temperature for 30 minutes. Furthermore, all the wells (1-12) were filled with $50 \mu \mathrm{l}$ of $0.5 \%$ chicken erythrocytes using a $50 \mu \mathrm{l}$ micropipette. Incubation was performed again at room temperature for 30 minutes or $4^{\circ} \mathrm{C}$ for 45 minutes. The data obtained were presented in descriptive form by calculating the percentage of positive samples. The total number of samples was compared with the number of samples collected.

\section{RESULTS}

\section{Hemagglutination and hemagglutination inhibition tests}

The results showed that ducks sold in the market were infected by ND virus. The results of sampling from ducks by region of origin are presented in Table 1 .

In the first week of sampling, 3 out of 14 pooled samples of duck cloaca derived from Mojosari showed positive results during the HA test, however, the result was negative when the HI-ND test was conducted. Meanwhile, 5 of 6 pooled samples of ducks which derived from Lumajang showed positive result during the HA test, however, only 1 pooled sample showed positive result during HI-ND test. In the second week of sampling, 7 out of 9 pooled samples of ducks from Mojosari showed positive results during the HA test, however, the result was negative when HI-ND test was conducted. Meanwhile, for the samples derived from Lumajang, there were 10 of 11 pooled samples of ducks with positive result during the HA test, however, only 1 pooled sample was positive 
during the HI-ND test. In the third week, the ducks from which cloacal swab samples were taken, were monitored and kept separately from the flock. When the HA test was conducted on the samples, all samples showed negative results. In the fourth week, a positive result was observed in 9 of 10 pooled samples of ducks derived from Mojosari using the HA test, however, the result was a negative result during the HI-ND test. Meanwhile, 7 out of 10 pooled samples of ducks from Lumajang showed positive results during the HA test, however, 6 pooled samples were positive when the HI-ND test was conducted. In the fifth week, 19 out of 20 pooled samples of ducks from Jombang showed positive results during the HA test, but there was only 1 positive pooled sample during the HI-ND test. In addition, this study also calculated the percentage of samples infected by NDV in the ducks throughout the pooled sample (Table 2).

Table 2. Number of positive and negative samples for Newcastle disease virus by the region of origin

\begin{tabular}{lcccc}
\hline Duck's origin & $\begin{array}{c}\text { Number of pooled } \\
\text { samples }\end{array}$ & $\sum$ Positive ND & \% Positive ND & $\sum$ Negative ND \\
\hline Mojosari & 33 & 0 & $0 \%$ & $3 \%$ \\
Lumajang & 27 & 2 & $0 \%$ & 25 \\
Sidoarjo & 20 & 0 & $0 \%$ & 20 \\
Jombang & 20 & 1 & $5 \%$ & 19 \\
\hline
\end{tabular}

Each pooled sample contained a cloacal swab sample from three ducks. ND: Newcastle disease

Table 1. Results of hemagglutination and hemagglutination inhibition tests for Newcastle disease virus isolated from ducks' cloacal swabs at the traditional live bird market center, Indonesia

\begin{tabular}{|c|c|c|c|c|c|c|c|c|c|c|c|c|}
\hline \multirow{3}{*}{$\begin{array}{l}\text { Week of } \\
\text { sampling }\end{array}$} & \multicolumn{12}{|c|}{ Regions } \\
\hline & \multicolumn{3}{|c|}{ Mojosari } & \multicolumn{3}{|c|}{ Lumajang } & \multicolumn{3}{|c|}{ Jombang } & \multicolumn{3}{|c|}{ Sidoarjo } \\
\hline & $\begin{array}{c}\text { Total } \\
\text { samples }\end{array}$ & $\begin{array}{l}\text { Positive } \\
\text { HA } \\
\text { samples }\end{array}$ & $\begin{array}{c}\text { Positive HI } \\
\text { samples }\end{array}$ & $\begin{array}{c}\text { Total } \\
\text { samples }\end{array}$ & $\begin{array}{c}\text { Positive } \\
\text { HA } \\
\text { samples }\end{array}$ & $\begin{array}{l}\text { Positive HI } \\
\text { samples }\end{array}$ & $\begin{array}{c}\text { Total } \\
\text { samples }\end{array}$ & $\begin{array}{l}\text { Positive } \\
\text { HA } \\
\text { samples }\end{array}$ & $\begin{array}{c}\text { Positive HI } \\
\text { samples }\end{array}$ & $\begin{array}{c}\text { Total } \\
\text { samples }\end{array}$ & $\begin{array}{l}\text { Positive } \\
\text { HA } \\
\text { samples }\end{array}$ & $\begin{array}{c}\text { Positive HI } \\
\text { samples }\end{array}$ \\
\hline I & 14 & 3 & 0 & 6 & 5 & 1 & --- & $\begin{array}{l}-- \\
--\end{array}$ & --- & --- & --- & --- \\
\hline II & 9 & 7 & 0 & 11 & 10 & 1 & --- & --- & --- & --- & --- & --- \\
\hline III & --- & --- & --- & --- & --- & --- & --- & --- & --- & 20 & 0 & 0 \\
\hline IV & 10 & 9 & 0 & 10 & 7 & 0 & --- & --- & --- & & --- & --- \\
\hline $\mathrm{V}$ & --- & --- & --- & --- & --- & --- & 20 & 19 & 1 & --- & --- & --- \\
\hline
\end{tabular}

HA: Hemagglutination, HI: Hemagglutination inhibition

\section{DISCUSSION}

Based on the obtained results of the study, 3-9 out of 100 pooled samples of ducks derived from several areas were infected with the NDV. The NDV prevalence was relatively low in ducks in the traditional livestock market. In previous studies, the isolation rate of NDV in ducks infected with JSD0812 strain was relatively low but the ducks showed clinical signs of disease or death (Dai et al., 2014).

Observation results during embryonic chicken egg incubation showed that the time of embryo death varied between three and five days after inoculation. The rapid death of an embryo could be caused by several factors, including the malignant strain virus, the contamination caused by germs, or the trauma to the embryo during inoculation. Moreover, "viral toxicity" caused by a partial replication cycle can lead to the death of infected cells, but it was not responsible for the production of infective offspring (Friend and O Trainer, 1972).

The current study was conducted on a type of Pekin ducks from several regions in Indonesia. Based on the result of the study, ducks coming from Mojosari and Sidoarjo were not infected by the NDV. In addition, the relatively low percentage of NDV was observed in the white Pekin duck being resistant to the development of clinical signs of ND, compared to the velogenic NDV. This was important for NDV epidemiology since the white Pekin ducks could shed the virus 20 to 30 days after the challenge, and vaccination against ND was very important to reduce virus elimination in the field (Nishizawa et al., 2007).

In the current study, there were samples which had high titer values during the HA test, but they indicted negative results after the $\mathrm{HI}$ test. This could occur because the virus isolated might not an NDV but another type of virus which had the characteristic of erythrocyte 
agglutination in the HA test, one of which is the avian influenza virus (Kim, Paldurai and Samal, 2017). In a study conducted in Brisbane, Australia, it was also found that $\mathrm{HI}$ antibody titers were much higher in ducks than chickens in the result of the experiment, and higher than the titers usually recorded in chickens (Bouzari, 2014). The immune response in the in-contact ducks indicated the transmission of the virus among ducks (Bouzari, 2014). In addition, differences in the composition of these proteins affected the speed of virus replication and determined the degree of virulence. The efficiency of protein F0 division and virulence of NDV depended on the presence of one or two arginines at the positions of 112 and 115 and phenylalanine at the position of 117 (Hines and Miller, 2012). The F1 active polypeptides mediated fusion between the virus lipid membrane and the host cell membrane (Rout, 2007).

The lentogenic virus had a single basic amino acid motif on the $\mathrm{F}$ cleavage site ${ }_{112} \mathrm{G} / \mathrm{E}-\mathrm{K} / \mathrm{R}-\mathrm{Q}-\mathrm{G} / \mathrm{E}-\mathrm{R}^{116}$ and $\mathrm{L}$ (leucine) in the residue of 117 and could be cleaved by protease enzymes, such as trypsin, found in the digestive tract and breathing (Kim et al., 2008; Choi et al., 2010). Mesogenic and velogenic strains had multiple basic amino acid motifs (arginine or lysine) on the $\mathrm{F}$ cleavage site ${ }_{112} \mathrm{R} / \mathrm{K}-\mathrm{R}-\mathrm{Q} / \mathrm{K} / \mathrm{R}-\mathrm{R}_{116}$ and $\mathrm{F}$ (phenylalanine) in the residue of 117 (Meulemans et al., 2002) and could be cleaved intracellularly by protease enzymes, such as furin, that was in various host tissues, and thus it could cause fatal systemic infection (OIE, 2012).

The management conditions are a factor affecting the spread of NDV in ducks. Ducks infected by the NDV generally showed different physical symptoms from healthy ducks. However, if symptoms are detected late by duck breeders it can cause the rapid spread of the NDV. Based on the results of previous studies, it was indicated that it is difficult to avoid contact between the natural waterfowl and the fowls. Accordingly, the reservoir of natural waterfowl and sensitive fowls operations, circulating lentogenic NDV strain, could represent a potential reservoir for velogenic NDV strain leading to the epidemic to the chickens (Meng et al., 2015).

The current study faced some limitations, for instance, there was no other type of observations to complete the results of the study regarding biological characteristics of fowls, especially ducks infected by NDV. The microscopic observation of cells infected by NDV could definitely shed more light on the findings. However, the obtained results of the current study revealed that NDV-infected ducks were present in the animal market in the Sidoarjo area, but at a relatively safe level.
The findings of the current study can be useful for veterinarians, practitioners, breeders, scientists, and livestock entrepreneurs in the efforts to prevent NDV infection.

\section{DECLARATIONS}

\section{Authors' contributions}

Aisyah Nur Azizah designed the study. Chairul Anwar collected the samples. Adi Prijo Rahardjo performed laboratory analysis. Aisyah Nur Azizah and Adi Prijo Rahardjo interpreted the results. All authors approved the final draft of the manuscript.

\section{Conflict of interest}

All authors have no conflicts of interest to declare.

\section{REFERENCES}

Bouzari M (2014). The response of ducks to V4 Newcastle disease virus and its transmission to contact ducks and domestic chickens. Veterinary Research Forum, 5(2): 145148 . Available http://vrf.iranjournals.ir/article_5392.html.

Choi KS, Lee EK, Jeon WJ and Kwon JH (2010). Antigenic and immunogenic investigation of the virulence motif of the Newcastle disease virus fusion protein. Journal of Veterinary Science, 11(3): 205-211. DOI: 10.4142/jvs.2010.11.3.205.

Dai Y, Cheng X, Liu M, Shen X, Li J, Yu S, Zou J and Ding C (2014). Experimental infection of duck origin virulent Newcastle disease virus strain in ducks. BMC Veterinary Research, 10(1): 1-9. DOI: 10.1186/1746-6148-10-164.

Friend M and Trainer DO (1972). Experimental Newcastle disease studies in the mallard, American Association of avian pathologists, DOI: 10.2307/1588747.

Hines NL and Miller CL (2012). Avian paramyxovirus serotype1: A Review of disease distribution, clinical symptoms and laboratory diagnostics. Veterinary Medicine International, 2012: 1-17. DOI: 10.1155/2012/708216.

Hu S, Wang T, Liu Y, Meng C, Wang X, Wu Y and Liu X (2010). Identification of a variable epitope on the Newcastle disease virus hemagglutinin-neuraminidase protein. Veterinary Microbiology. 140(1-2): 92-97. DOI: 10.1016/j.vetmic.2009.07.029. Epub 2009 Aug 8.

Kim LM, Suarez DL and Afonso CL (2008). Detection of a broad range of class I and II newcastle disease viruses using a multiplex real-time reverse transcription polymerase chain reaction assay. Journal of Veterinary Diagnostic, 20: 414425. DOI: $10.1177 / 104063870802000402$.

Kim S, Paldurai A and Samal SK (2017). A novel chimeric Newcastle disease virus vectored vaccine against highly pathogenic avian in fluenza virus. Virology, 503: 31-36. DOI: 10.1016/j.virol.2017.01.006. 
Meng C, Qiu X, Yu S, Li C, Sun Y, Chen Z, Liu K, Zhang X, Tan L, Song C, Liu G and Ding C (2015). Evolution of Newcastle disease virus quasispecies diversity and enhanced virulence after passage through chicken air sacs. American Society for Microbiology, 90(4): 2052-2063. DOI: 10.1128/JVI.01801-15.

Meulemans G, Van Den Berg TP, Decaesstecker $M$ and Boschmans M (2002). Evolution of pigeon Newcastle disease virus strains. Avian Pathology, 31(5): 515-519. DOI: $10.1080 / 0307945021000005897$.

Nishizawa M, Paulillo AC, Nakaghi LSO, Nunes AD, Campioni JM and Doretto Júnior (2007). Newcastle disease in white pekin ducks: response to experimental vaccination and challenge. Brazilian Journal of Poultry Science, 9(2): 77-79. DOI: 10.1590/S1516-635X2007000200008.

OIE (2012). Manual of diagnostic tests and vaccines for terrestrial animals. World organisation for animal health. Available at: https://www.oie.int/standard-setting/terrestrialmanual/.

Rout SN (2007). The role of Newcastle disease virus internal proteins in pathogenesis. Available at: https://drum.lib.umd.edu/handle/1903/7422.

Samal SK (2011). Newcastle disease and related avian paramyxoviruses. The biology of paramyxoviruses. Caister Academic Press Norfolk, UK, 69-114. DOI: 10.20506/rst.19.2.1231. 